\title{
Individual Characteristics and Earlier Sexual Behavior: A Differential Study of Teenagers' Sexual Violence in Abidjan
}

\author{
KOUAKOU Ossei \\ OTEME Apolos Christophe \\ YAO-Ackah Mathilde Ebloumi \\ Department of Psychology \\ University Félix Houphouët Boigny \\ Abidjan-Côte d'Ivoire
}

\begin{abstract}
The study examines the relationship between age, gender and personality of victims of sexual violence through their first sexual experiences. On the basis of a questionnaire, 98 adolescents (48 girls and 50 boys) aged 13 to 20 years, were interviewed with the goal of identifying those whose first sexual experience was forced from those whose first sexual was consented. The Eysenck personality test (EPI) was subsequently administered, in order to determine their personality trait (introvert or extrovert). The results reveal no evidence suggesting that the participants' first sexual intercourse was consented. On the other hand, the relationship between consent to sexual intercourse and the partner's age is clearly demonstrated. This means that the older the partner, the less the consent is observed in the subject.
\end{abstract}

\section{I- Introduction}

Sexuality is an important dimension of human's life insofar as it ensures the survival of the species. However, because of its intimate nature, sexuality remains a taboo in most communities. Indeed, it is difficult for an individual to disclose overtly information about his/her sexuality. That is why sexual abuse is often hidden and the victims suffer inwardly in secret. Various surveys indicate that women and children are the main victims of sexual violence (Mbassa, 2000; Runyan et al., 2002 and Sos sexual violence, 1998, 2002).

The consequences of that violence on the victims are of various kinds and can be divided into three types: physical, psychological and socio-economic. In terms of physical consequences, there are mainly sexually transmitted infections or HIV/AIDS, unwanted pregnancies, etc. At the psychological level, we can name among others post-traumatic stress, depression (suicidal behavior), anxiety, memory disorder, severe mental illness (withdrawal on oneself), sexual disorder (frigidity, refusal of sexuality, perversion and sexual deviation), sadism or masochism, etc. From the socio-economic point of view, we observe family and social rejection, stigmatization, prostitution, drug addiction or alcoholism, professional apathy, loss of the ability or inability to carry out duties, decreased academic performance and failure at school (Ciavaldini, 2012 ; Lopez, 2013; Mucchielli, 2011; Peromingo, 2012; Salmona, 2013). A variety of non-governmental organizations (e.g., Save the Children, Care International, BICE, NGOs forum), The United Nations system (UNFPA, UNICEF, OCHA) and certain state organizations (the National anti-GBV Committee, social centers ...) make the fight against sexual violence their hobbyhorse.

Like several other non-governmental organizations, the NGO helping victims of sexual violence is contributing to the fight against this phenomenon with the support of its partners such as ECPAT International and Save the Children in Côte d'Ivoire. It regularly receives victims for holistic care (medical, psychosocial and legal-judicial). Within the framework of its activities, during listening sessions of victims, and in the course of certain testimonies, it very often happens to learn that the first sexual experiences are very premature (before puberty) and imposed by force without the consent of the children or adolescents. For that reason, they constitute sexual violence or abuse. As such, early sexual behavior deserves to be analyzed thoroughly in order to detect any links or relationships with sexual violence. 
In this perspective, the present study aims at examining the teenages' first sexual experiences in relation to psychological and biological characteristics, namely, their personality, age and gender. For the implementation of the work, we propose to show in the following part the justification of the study (the thesis), the dealt with methodological approach, the results we achieved and the discussion.

\section{Ii- Statement of the Thesis}

Adolescence is a period characterized by the physical and psychological metamorphosis of the subject. As far as the physique is concerned, both boys and girls experience changes that result in a "weight-for-height" increase, that is to say weight gain and increase in height. At the psychological level, especially intellectual, this period is characterized by the acquisition of formal thought (Piaget, 1998). On the affective level, we observe that the sexual impulses of the individual, which was in the latent state for a certain time, reactivate with new intensities and in a much more concrete manner. Unlike the pregenital stages where the satisfaction of the libido is only fulfilled by fondling the erogenous zones like the mouth, the anus, the penis and the contact with the parents, in adolescence, there is a reversal of the trend. The individual becomes more and more attracted by the other sexpersons who are not part from the family dyad. Thus, the sexual affairs are displayed in this period. The adolescent feels a strong desire to come in close contact with the individual of the other sex (Dolto, 1988; Freud, 1981 and Philippe, 2004). This psychological state of the adolescents makesthem vulnerable to potential sexual abusers in search of any situation that could enable them to satisfy their libidos. Specifically, Bozon (2013) found that the median age of the first sexual intercourse, that is, the age at which half of the sounded-out population have sex declined from 20.6 to 17.6 years for girls and 18.6 to 17.2 years for boys within 50 years. Some studies and surveys even point out that, children under puberty are compelled to early sexual behavior by some adults. They are consequently subject to sexual violence (UNOCI, 2016; Save the Children, 2013; SOS Sexual Violence, 2013 to 2016).

Sexual precocity is the tendency to have sex before the age of majority that is 18 years old, according to the Convention on the Rights of the Child (CRC) of 1989 ratified by most of the states, including Côte d'Ivoire. Because of the vulnerability of the minor, sexual behavior during this period may be subject to violence, especially if the partner is an adult or older.

In the broad sense of the word, sexual violence involves all acts of a sexual nature against the will of a person or without his or her consent. More specifically, OMS (2012, p. 2) views sexual violence as "any sexual act, attempt to have a sexual act, commentary or advances of a sexual nature, or acts aiming at trafficking or otherwise directed against sexuality of a person using coercion, taken by a person apart from his or her relationship with the victim, in any context, including but not limited to home and work place ". Coercion often includes the use of force in varied degrees, psychological intimidation, blackmail and threats. Sexual violence therefore comprises acts ranging from verbal harassment to forced penetration as well as various forms of coercion from social pressure, intimidation to physical force. Women and children are the greatest victims due to their vulnerability (SOS sexual violence, 1998, 2002; Maguiabou, 2012; Diouf et al., 1995; Care International, 2011-2013, 2014; OMS, 2012, 2014; Unicef, 2014; Save the Children, 2008, 2013). Indeed, numerous studies suggest that women and fair-sex minors constitute the bulk of rape or sexual violence victims. For instance, the GIZ-Cameroon report (quoted by Maguiabou, 2012) argues that among the raped girls and women who took steps for a care or lodged complaint in Cameroun, $12 \%$ are 10 years at the most and the average age is 15 years. Thus, $18 \%$ of the victims were raped by a member of the family, $9 \%$ were gang-raped; $18 \%$ had a sexually transmitted infection (STI), or even HIV / AIDS; $24 \%$ of girls became pregnant

In Côte d'Ivoire, SOS Sexual Violence reports for the last five years (2010-2015) reveal 205 cases of sexual violence, including 146 cases of rape, that is, rape represents $71.2 \%$ compared to $28.8 \%$ of other forms of sexual assault (harassment, fondling ...). The bulk of victims (67.3\%) are girls aged between 1 and 19 years. Indeed, precisely speaking, girls below 11 years old who are subject to rape represent $37.6 \%$ compared to only $7.8 \%$ for boys. According to the UNOCI report (op.cit), from January 1, 2012 to December 31, 2015, the Human Rights Division (HRD) has documented 1129 cases of rape involving 1146 victims and distributed as follows: 178 victims including 90 children in 2012, 462 victims including 296 children in 2013, 336 victims including 239 children in 2014 and 170 victims including 136 children in 2015. Most of the victims were women and girls, but there were twelve (12) cases of rape against boys. Sixty six percent (66\%) of registered victims were 2 to 17 years old children. 
However, the figures seem to be inconsistent with the daily reality since sex is a taboo. Indeed, the studies reviewed here concern the victims who have asked for aid or psychosocial care in the relief organizations. Probably, some other victims suffer in silence, because they never dared to talk about it.

Otherwise, diverse causes or factors lead to sexual violence. Specifically, factors apart from the victims' will, namely sexual perversity, personality disorders of the attackers, parental carelessness, family dislocation, negative influence of peers, influence of media, internet, and so forth can be envisioned. Adding to those are internal factors resulting from various high-risk behaviors of the victims, that is, the consumption of psychotropic products such as alcohol, drugs, tobacco, and early sexual behavior. Presumably, these factors are likely to bring about aggressiveness, various forms of violence and sexual precocity (Gnonlonfoun et Gnonlonfoun, 2007; Lipsey et Derzon, 1998; Miangotar, 2011; Thibaut, 2013; Tignol et al., 2001).

These different surveys mainly concern perpetrators. And victims are neglected. Besides, features related to the personality of the victims are not explicitly cleared. Yet, they are liable to determine the victims as well as perpetrators' sexual behavior. In this respect, Proulx et al. (1994) argue that the disturbances of the personality have implications on rapes. For instance, rapes would be as well the consequence of a sexual preference for rape as the absence of a sexual intercourse preference between a man and a willing adult woman. Deficiency regarding the social abilities required to access such a female partner can be added too (Abel et al., 1981; Bond and Evans, 1967; Corazza, 1997; Gamache et al., 2014). Psychologists' works reveal there are several types or kinds of personalities (Jung, Cattel, Rorschach, quoted by Delay and Pichot, 1990). But, according to the approach by trait, the perpetrators generally show the kind of personality characterizing most of the individuals, that is to say, the introvert and the extrovert. In the first case, we have persons who have a tendency to withdraw into themselves whereas in the second, we deal with those who easily familiarize with others.

Owing to the privacy and the taboo nature of sexuality, it is relevant and logical to think that these personality features strongly determine or influence individuals' sexual behavior. This may be the same for age and sex since they are individual biological features determining the different features of personality. Yet, from our current knowledge, the studies aiming at elucidating this kind of relationships are quite inexistent. Thus, it seems to be relevant to carry out that survey focusing on highlighting the relationships between age, sex and the personality of the victims of sexual harassment through their first sexual intercourse. This survey emerges from the idea that the first intercourse is generally like a sexual harassment since it is done without the individuals' will. They often surrender under the influence or the domination of their partners who are generally older or stronger than them. This fact or phenomenon varies from sex to sex, age and the personality of the subjects (people). In a specific way, we can put forward the following hypotheses:

Hypothesis 1: The number of introvert willing teenagers is higher than that of their extrovert peers. Hypothesis 2: The number of willing young boys is higher than that of their peers' young girls.

The number of the willing less-aged teenagers compared to their partners is lower than that of their older willing peers' in comparison with their partners.

\section{Iii- Method}

\section{3-1. Participants}

This survey is conducted through teenagers all along the ten sub-areas of the district of Abidjan in accordance with all sexual active comers approach. In total, they are 98 with 48 girls and 50 boys. Their first sexual partners have been determined in the light of their answers. They (the partners) are equal in number and proportions because there has not been a homosexual partner among them. During the survey, their ages ranges from 13 to 20. The average age of the victims and guilty or sexual partners is nearly identical and characteristic of their status of less than 18 year-minors. The average age of the victims is 17.30 while that of the guilty (sexual partner) is 17.26. It is of paramount importance to underscore that amongst the victims there are two subjects under 10. Concerning the features of personality, the participants are dispatched in the following way:

A number of 40 extravert individuals with 16 girls and 24 boys. And 58 introverts with 32 girls and 26 boys. The sexual partners (victims or guilty) of the participants at stake is divided into three categories. It is about relatives $(8.16 \%)$, circles $(70.41 \%)$ and some unknown or strangers $(21.43 \%)$.

\section{3-2. Measuring instruments}

The instrument implemented to realize the survey is the questionnaire. It has the subsequent features.

\section{- Questionnaire}

210 
Within the framework of the study, the questionnaire identified participants who had their first sexual intercourse unwillingly or willingly. It is important to contend that we did not take into account legal consent which states there is no consent if the sexual partner is under 18 years old. In that case, any act of a sexual nature taken against a minor by an adult is regarded as sexual abuse or violence (Ivorian Penal Code). On the contrary, we have prioritized a psychological approach which permits to distinguish a deliberate act from coercion. Indeed, from a psychological point of view, we think that a teenage minor who takes a deliberate action to satisfy his or her curiosity is not in the same mental dispositions as the one who was forced to do so. Our argument is based on the fact that from an intellectual point of view, the adolescent's level of growing up allows him/her to live on the principle of reality, even if he has no experience (Piaget, 1998). Likewise, Dolto (1988: 21) asserts that "the crucial fact that testifies the disconnection with childhood state is the possibility of separating imagination from reality, dream from non-virtual matters;" Contrary to the legal approach; we vigorously contend that consent is relevant.

So, on the one hand the questionnaire permitted to identify adolescents whose first sexual experience was restrictive and on the other hand those who willingly have the first sexual experience.

\section{- Personality Test (PPE)}

PPE is part of personality questionnaires; it consists of 57 items. Each dimension is measured or assessed using 24 questions $(24+24=48)$, the 9 remaining questions are used for judging the subject's sincerity (scale of lie which allows to measure or detect whether the subject has responded honestly or no). The operation may be individual or collective. For instance, the test permits to highlight the introversion as well as extraversion trait. Introversion is characteristic of a self-effacing and introspective person. Such a withdrawn and distant human being likes reading, but does not have many friends. Besides, an introverted individual always tends to plan and carefully takes actions. Vigilant about the moment impulses, the introvert have a well-regulated life and dislike being overexcited. They successfully control their feelings and rarely attack. On the other hand, extraversion characterizes a friendly, chatty and very sociable individual who dislikes reading or solitary work. He is unpredictable, jokey, optimistic, and carefree, seeks thrill and has plenty of nerve. An extravert person also tends to attack and badly controls his/her feelings. He is scarcely trustworthy. The study uncovered the two personality traits among participants. What results have we achieved with those participants? The following section provides some details.

\section{Vi- Results}

We firstly examine the relationship between personality and consent to first sexual intercourse. Then, we analyze consent following sex. And finally, we focus on consent in accordance with the partner's age

\section{Personality and consent to first sexual intercourse}

\begin{tabular}{llll}
\hline & Consent & & Total \\
\cline { 2 - 4 } & Yes & No & \\
\hline Extravert & 31 & 09 & 40 \\
Introvert & 35 & 23 & 58 \\
Total & $\mathbf{6 6}$ & $\mathbf{3 2}$ & $\mathbf{9 8}$ \\
\hline
\end{tabular}

Statistical analysis of the data unearths that the calculated Chi-square $(\chi 2 \mathrm{c}=2.43)$ is less than the theoretical Chi square $\left(\chi 2^{2}\right.$ th $\left.=3.84\right)$ at the threshold of .05 . There was no significant difference between sizes of both subjects' groups. Therefore, there is no difference between the consent to first sexual intercourse and the subjects' personality. So, we can remember that adolescents of introverted personality are no less willing than their peers of extravert personality.

\section{Consent by Teenagers' Gender}

\begin{tabular}{llll}
\hline & Content & & Total \\
\cline { 2 - 4 } & Yes & No & \\
\hline Girls & 32 & 16 & 48 \\
Boys & 35 & 15 & 50 \\
Total & 67 & 31 & 98 \\
\hline
\end{tabular}


The statistical analysis of the data shows that the calculated chi-square $\left(\chi 2^{2} \mathrm{c}=0.10\right)$ is less than the theoretical chi-square $\left(\chi 2^{2}\right.$ th $\left.=3.84\right)$ at the threshold of .05 . There is no significant difference between the subjects' groups. Therefore, we can bear in mind that girls are no less willing than boys.

\section{Consent by Sexual Partner's Age}

\begin{tabular}{llll}
\hline & Consent & No & Total \\
& Yes & 13 & 43 \\
\hline Older partners & 30 & 17 & 40 \\
Younger partners & 23 & 01 & 15 \\
Peers & 14 & $\mathbf{3 1}$ & $\mathbf{9 8}$ \\
Total & $\mathbf{6 7}$ & & \\
\hline
\end{tabular}

At this level, we notice that the calculated Chi square $\left(\chi 2^{2} \mathrm{c}=4.95\right)$ is greater than the theoretical Chi square $\left(\chi 2^{2}\right.$ th $=3.84)$ at the .05 threshold. There is a significant difference between the numbers of the different subjects groups. Consequently, there is a difference between consent to first sexual intercourse and the partner's age. In other words, the older the partner is, the less the subject's consent occurs. However, the consent is almost all effective for the subjects of the same age. The preceding results deserve to be discussed in the subsequent lines.

\section{V-Discussion}

The study allowed us to uncover the characteristics of early sexual intercourse victims. So, we remember that the average age for first intercourse is around 17 years as well for victims as perpetrators or sexual partners. It is important to contend that the piece of information about the victims is plausible although we should voice reservations about it since partners or perpetrators' ages have been given by the victims themselves. Obviously, they did not provide accurate information especially as some were unknown to the victims.

To a certain extent, the study determined the proportion of participants following gender and personality. In this respect, we remarked that there are more girls than boys among the introverted subjects. The same goes for the extroverts. By showing our sample features, the observation also raises questions about the proportion of different personality traits in the general population. Are girls more introverted than boys? Are boys conversely more extroverted than girls? We should keep in mind that the study did not intend to address these issues although it does give us some ideas. However, to some extent, it seems to be in line with Diop's study (2014), which reveals that introverted adolescents tend to have early sexual intercourse than the extrovert. But, it is necessary to argue that not all early sexual intercourse is sexual violence.

As far as the subjects' characteristics are concerned, we bear in mind that the study divided the partners of the first sexual experience into three entities namely relatives, cases of incest, friends or acquaintances and strangers. Thus, we can argue that sexual violence is generally perpetrated by circle of friends or persons known to the victims' parents. These findings corroborate through most of the studies implemented in this field (Mbassa, 2000; Miangotar, 2011; Pinheiro, 2006 and SOS Sexual Violence, 2002).

The assumption that consent changes in accordance with personality did not turn out to be true. Indeed, data reveal that consent or dissent to first sexual intercourse is not dependent of personality traits. Similarly, the link between consent and sex are unproven. In other words, it is impossible to argue that girls are more willing than boys or vice-versa. So, we remember that girls or boys' first intercourse occurs more or less in a similar way.

Notwithstanding, the study allows us to assert that consent to first sexual intercourse differs according to the partner or the perpetrator's age. Indeed, the older the partner, there is less consent. In that case, violence or sexual abuse happens. Such an observation confirms the results of Dozois' work (1994), which notes that aggressors are often older than their victims. All this corroborates the meaning of sexual violence, which refers to the inequality of power between the victim and the perpetrator for instance, according to the AMTV report (2015, p.34) "this culture of rape can only flourish in an unequal context marked by interpersonal violence: sexual violence is an instrument of power and usually takes place in situations of oppression ". However, when the individuals concerned are contemporaries, they tend to consent to the sexual act. It generally involves over 16 years old teenagers. In such circumstances, the sexual act performance equals to a satisfaction of curiosity. And this is very common among adolescents (Mannoni, 1979). 
Beyond the findings, the study has tested hypotheses within specific methodological conditions. And this led to results that follow the lead of previous studies. However, they remain specific and open prospects for future research. It is therefore important to take into account the difficulties of the results achievement.

\section{Conclusion}

From the study, we remember that the first sexual intercourse of the study participants was generally imposed by the partners. They occur without the consent of the persons concerned regardless of their sex. As such, this is sexual violence. Moreover, it happens that consent or dissent to sexual act does not depend on the difference in sex or personality. In other words, irrespective of their personality, young boys and girls react to the first sexual act in a substantially identical way especially with regard to consent

The study also permitted to know that sexual violence is perpetrated on young children. Thus, we believe that the psychological impact of that violence on the children is very serious because of their frailty, their great dependence, their powerlessness and their lack of experience. We fear that their traumatic memory, through the use of "self-treatment" anesthetic defense mechanisms, repeat the same violence on others in adulthood. We would then experience a cycle of violence at the level of social life.

\section{References}

Abel, G.G., Blanchard, E.B. and Barlow, D.H. (1981). The effects of stimulus modality, instructional set, and stimulus content on the objective measurement of sexual arousal in several paraphilias. Behaviour Research and Therapy, 19, 25.

Biyong, I. (1990). Contribution à l'étude médico-psycho-sociale des mauvais traitements des enfants de 0 à 15 ans (à propos de 44 cas à l'hôpital central de Yaoundé). Thèse de Médecine. Non publiée.

Bond, I. K. and Evans, D. R. (1967). Avoidance Therapy: Its Use in Two Cases of Underwear Fetishism. Canadian Medical Association Journal, 96, 1160-1162.

Ciavaldini, A. (2012). Prise en charge des délinquants sexuels. Paris : Yapaka.be, 60 p.

Corazza, G. (1997). Personnalité et comportement pédophile. Médecine et hygiène, 55 (2157), 647-649.

Delay, J. et Pichot, P. (1990). Abrégés. Psychologie. Paris: Masson $3^{\mathrm{e}}$ édit, 489 p.

Diop, A. (2014). Pratiques éducatives parentales, caractéristiques psychologiques et comportements sexuels des adolescents. Mémoire de Master de Psychologie. Univ. FHB, Cocody, 55 p.

Diouf, A., Gaye, A., Sangare, M. et coll. (1995). Prise en charge médicale de victimes présumées d'agression sexuelle à Dakar, Sénégal. A propos de 25 cas. Contraception, Fertilité, Sexualité- Journal 23 : 267-270.

Dolto, F. (1988). La cause des adolescents. Paris : Robert Laffon. 384 p.

Dozois, J. (1994). Adolescents et agresseurs sexuels : bilan d'une recherche. Revue Criminologie, 27 (2), 71-85.

Freud, S. (1981). Trois essais sur la théorie de la sexualité. Paris : Coll. Idée., $3^{\text {ème }}$ édition, 224 p.

Gamache, D., Diguer, L. \& Laverdiere, O. (2014). Agressions sexuelles commises par des adolescents: relations entre des dimensions de l'organisation de la personnalité et des caractéristiques du délit: la violence et son contexte. Evolution psychiatrique, 79 (4), 725-738.

Gnonlonfoun, I. et Gnonlonfoun, M. A. (2007). Influence de l'internet sur le comportement sexuel des jeunes du Benin. Mémoire de DEA.

Lipsey, M.W. et Derzon, J.H. (1998). Predictors of violent or serious delinquency in adolescence and early adulthood: A synthesis of longitudinal research. In: Serious and Violent Juvenile Offenders: Risk Factors and Successful Interventions. R. Loeber and D.P. Farrington (Eds.). Thousand Oaks, CA: Sage Publications, pp. 86-105.

Lopez, G. (2013). Enfants violés et violentés. Le scandale ignoré. Paris : DUNOD, 248 p.

Maguiabou, A. (2012). Détérioration de l'image du corps chez l'adolescente victime de violence sexuelle. Revue Camerounaise de psychologie clinique :Violence (s), 61-76.

Mannoni, P. (1979). Troubles scolaires et vie affective chez l'adolescent. Paris :Les Editions ESF, $142 \mathrm{p}$.

Mbassa, M. D. (2000). La problématique des enfants victimes d'abus sexuels en Afrique ou l'imbroglio d'un double paradoxe : l'exemple du Cameroun. Child abuse \& neglect, 25 (1) 109-121.

Miangotar, Y. (2011). Environnement familial et comportement sexuel des adolescents au Burkina Faso. Thèse de Doctorat, $231 \mathrm{p}$.

Mucchielli, L. (2011). L'intervention de la violence. Des peurs, des chiffres et des faits. Paris : Fayard, $340 \mathrm{p}$.

OMS (2012). Comprendre et lutter contre la violence à l'égard des femmes, Genève, $8 \mathrm{p}$. 
OMS (2014). Global Status Report on Violence Prevention, Genève, 292 p.

Peromingo, S. (2012). Je suis morte ce jour là. Paris : Flammarion, 235 p.

Philippe, J. (2004). Introduction à la psychanalyse. Paris : Payot, 576 p.

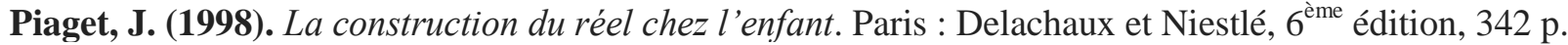

Pinheiro, P. S. (2006). World report on violence against children. United Nation Publishing, 357 p.

Proulx, J., Aubut, J., Perron, L., et McKibben, A. (1994). Troubles de la personnalité et viol : implications théoriques et cliniques. Revue criminologie, 27 (2), 33-53.

Rapport d'enquête, Association Mémoire Traumatique et Victimologie (AMTV), (2015). Impact des violences sexuelles de l'enfance à l'âge adulte. Déni de protection, de reconnaissance et de prise en charge : Enquête Nationale auprès des victimes. 368 p.

Salmona, M. (2013). Le livre noir des violences sexuelles. Paris : DUNOD, 341p

Runyan, D. et al. (2002). Child abuse and Neglect by parents and other caregivers. In, Krug EG et al. (Eds.). Rapport mondial sur la violence et la santé. Genève, OMS (pp.75-104).

Save the Children (2008). Aucun recours. La sous-représentation de l'exploitation et de la violence sexuelles subies par les enfants aux mains des travailleurs humanitaires et des soldats de la paix. London : ECIM 4AR $\mathrm{UK}, 40 \mathrm{p}$.

Save the Children (2013). Crimes innommables contre les enfants. Violences sexuelles en situation de conflit. London : ECIM 4AR UK, 57 p.

Sos violences (1998). Rapport de l'enquête menée à la maison d'Arrêt et Correction d'Abidjan auprès de 200 agresseurs sexuels.non publié, $30 p$

Sos violences sexuelles (2002). Rapport d'enquête. Abus sexuels en milieu scolaire en Côte d'Ivoire. Non publié, $26 \mathrm{p}$

Sos violences sexuelles (2013 à 2016). Rapports d'activités. $280 \mathrm{p}$.

Thibaut, F. (2013). Approche psychiatrique des déviances sexuelles. Paris : Springer, $130 \mathrm{p}$.

Tignol, J., Martin, C., Auriacombe, M. (2001). Etude de cas : témoins de la prévalence de la timidité, de la phobie sociale et de la personnalité évitante dans les troubles sexuels masculins. L'Encéphale, 27 (2), 418422.

UNICEF (2014). Hidden in plain sight: A statistical analysis of violence against children, 1 New York, $202 \mathrm{p}$. 